University for Business and Technology in Kosovo

UBT Knowledge Center

Oct 27th, 1:00 PM - 2:30 PM

\title{
The development of the concept of "public space" in Tirana
}

\author{
Eduina Zekaj \\ Polytechnic University of Tirana, eduinazekaj@ymail.com
}

Follow this and additional works at: https://knowledgecenter.ubt-uni.net/conference

Part of the Architecture Commons

\section{Recommended Citation}

Zekaj, Eduina, "The development of the concept of "public space" in Tirana" (2017). UBT International Conference. 4.

https://knowledgecenter.ubt-uni.net/conference/2017/all-events/4

This Event is brought to you for free and open access by the Publication and Journals at UBT Knowledge Center. It has been accepted for inclusion in UBT International Conference by an authorized administrator of UBT Knowledge Center. For more information, please contact knowledge.center@ubt-uni.net. 


\title{
The Development of the Concept of "Public Space" in Tirana
}

\author{
Eduina Zekaj \\ Faculty of Architecture and Urban Planning, Polytechnic University of Tirana,
} Albania

\begin{abstract}
The term "public space", also known as urban space is a pretty old phrase, but was used as e concept with a clear definition during the modern era. The evolution of this term is well known in Tirana, because of its constant development especially in the recent projects.

The first attempts started in 1914, but by that time there did not exist a real concept of the public space, which accordingly was affected by the citizens' lifestyle. Public spaces in Tirana have changed a lot since then by recreating the concept of "public use". There are many examples of squares, streets and parks which have gone through the process of change over the years and have affected people's lives.

Our project is an example of some small neighborhood squares that have turned into landmarks in Tirana. We finally came to the conclusion that the public space is one of the most important elements that represent a healthy and balanced life.
\end{abstract}

Keywords: urban space, evolution, lifestyle, square, landmark.

\section{The definition of space}

There are many quotes written and introduced by many architects and several other professionals about "space" and especially the terms like "public space" and "urban space". Many architects and urban planners think that they are totally different concepts, whereas many others say they have the same meaning. I will define this concept with the term space, as I think it entails all the compounds of that concept.

"Space can be formed from the relations that occur between the object/s and the person who perceives it/them" 1 This is a definition taken from the book "Reading Space"of an Albanian architect researcher, Maksim Mitrojorgji who has studied the definition of space in the old traditional Albanian cities. He defines space as a not necessarily physical relation between the objects and the person who perceives them. This definition gives a new meaning to the term "space" or we can say it gives another dimension - the non-physical one. These relations that occur between the person and the objects surrounding him can be perceived by the human senses: can be seen from the eyes, can be touched, can be listened to or even can be smelled and they play a major role on the creation of the space properties. This leads to the conclusion that the socalled "experiencing of space" is in general a biological function necessary for our adaption to the surrounding environment. Each one of us can create his own "space" by isolating a small part of nature, for example: an umbrella on the beach with two deckchairs is now a separated area from the nature itself and can be called "my space", but not necessarily "my property". The need of human beings to control the things around them has urged the need of having properties and calling a particular thing "theirs". Upon his existence, a person has developed the way of creating "his space" by keeping in mind not only the utility factor, but also the aesthetical one. At this

1 "Reading space" Maksim Mitrojorgji - "Duke lexuar hapësirën". 
point in a person's life there are two kinds of spaces "the interior architectural space" which is defined by the floor, the walls, the ceiling and the "urban space" defined by the walls of the other buildings, the streets, the squares and their urban elements.

\section{History of the "public space" concept in Albania}

There is a great debate in Albania and especially in Tirana on what is called "mine" and "notmine". Albania has gone through major historical regimes and also different ways of treating space. With the development of history people have named space with different labels and have used it different ways. My case study will be mostly the main boulevard of Tirana and the spaces it contains. In the history timeline I would like to divide it in some groups of years and explain the relation of Albanians with a particular space in Tirana.

The first period we will analyze is the prehistoric period. The first traces of human existence in the Albanian territory and their relation to space are found in Xarë and Mount "Dajt" in Tirana. At that time the term space was linked to the urge of shelter and food as people lived in tribes and shared their settlements with each other by not defining "my space" and "public space", but by using the terms of community space that belonged to one specific tribe. Until people started to build settlements on a specific territory they would do all their activities there and protect it. These are the first traces of public space used by a specific tribe.

The second period is the Antiquity when the Illyrian tribes inhabited the Albanian territory. At that time the space belonged to everyone and was managed by a king or queen, for example the tribes that resided central Albania were the Ardiaei with queen Teuta, Taulantii and Albanoi. Space was considered to be property of the tribe and was used by the community, but was also managed by the queen or king of the tribe. At this point of history we see the first attempts of the term public space similar to the one we have today.

The third period is the Middle Ages when the territory was divided into principalities and the "public space" was managed by the head of the principate and given function by the people who lived there. During the Ottoman period the public squares and bazaars got a new oriental meaning and function that we inherit today almost unchanged in many public spaces of Albania. Especially the bazaar concept is one of the most traditional terms of the Albanians way of life, the need to gather at one specific place and purchase things, but also use it to meet friends and family. The oriental impact at that time, changed the lifestyle of the Albanian citizens and derived to the creation of the bazaar areas.

The fourth period is the Modern era that includes the after-Independence period marking major changes in the Albanian lifestyle and also in the use of "space". The most major changes happened during the regime of King Zog I, also linked to the changes in the Albanians quality of life. During that time Albania went through major renovations of the "public spaces" also assisted by Italian architects that gave a meaning to many public spaces in Tirana.

The fifth period is the communist period. During that time the term "public" got an overall meaning through Albania, because at that time everything was considered public and belonged to the state, the only difference with the other regimes was that the "space", the built one and the non-built one was managed by the people who lived on that space.

The sixth period is democracy, when what was considered public started to belong to the individuals living in it. The main problem that we deal with today is that the term "public" is still unclear because of the communist ideas. When the regime changed the common spaces started to have many owners and that is considered a major problem in a capitalist society where properties are sold and bought every day. This problem started to solve when the main squares and the small ones were bought by the state or the municipalities and were considered their property, but belonged to the citizens and of course were used by them.

The main example that has gone through major changes and a thousand project ideas is "Skanderbeg" square, the center of Tirana. Through many years it has changed its face, but never 
its function. The main problem with "Skanderbeg" square was the lack of use by the public which I would like to show with a clear example, a story that happened to me and my friends, who are part of a non-profit organization called "Urban Sketchers Albania". Members of this organization were gathered that day as we do every Sunday and went at the "Skanderbeg" square which at that time looked like an ellipse with grass all over and the "Skanderbeg" monument in the middle and we thought that the best way to sketch the center of Tirana was by standing around the monument facing the buildings and sketching a bigger scale sketch all together. So we took our places, we measured what each one of us would sketch and then we were told to move immediately by the security staff of the municipality building. We asked them for the reason and they said: "You are not allowed to step in here, this is a public space, it's not for you!". This has triggered us for years and is one of the main reasons why I decided to choose to study this topic because I believe that everyone should know the story of every public space we step on now and how much the Albanian mentality has changed over the years.

\section{Tirana's public spaces evolution}

During the $18^{\text {th }}-20^{\text {th }}$ century the small and modest city took the appearance of a commercial city from the economic needs of the area. It stretched around its center where the bazaar was built and the two most distinguished mosques. The main arteries radially formed, connecting the center of the city with the rarely inhabited. Despite the changes, the city maintained its physiognomy. There were some public spaces we can mention such as the square in front of the old Mosque and Et'hem-Bey Mosque, the Square of Prayers (Namazgjaja) in Tabak neighborhood (today Ali Demi), the Military Parade square that coincides with the Shallvareve area, and the Albanian square before the Republic Cinema. They were used for different purposes that accompanied the oriental lifestyle.

During Austro-Hungarian invasion we have the first drawn document, which is a plan of Tirana's topographical situation in 1917. At this plan the city historically evolves around the cell of the bazaar. The residential area extends mainly on the northern and eastern side. This element describes the oriental influence on the Albanians life. The fact the bazaar area was one of the main areas and public spaces used at the time states once again the Albanian spirit of gathering together to buy things and to chat, drink a coffee and rumor a bit. A very important statement is that the bazaar drawn at the 1917 plan is the old bazaar, where today lays the Opera building which is very close to the "Skanderbeg square". This is one of the main reasons that links these two spaces together, the center of Tirana and the "bazaar lifestyle".

In 1924 the situation is as follows: the most important and economic part was the old bazaar of Tirana. The bazaar areas were normal streets with archery, since Tirana had very strong crossroads. This makes the bazaar a very powerful element, which is a characteristic of the oriental cities.

In 1925 king Zogu requires an Italian architect. Roads began to be built along with high-class villas, but an urban plan does not exist yet, a regulatory plan was required to control the demographic development of the city. King Zog wants the old and new bazaar to be split into two stores of livestock trading and items trading. Armando Braşini brings a neoclassical architectural spirit. He seeks to change the Oriental character into something European. He projects a boulevard that would have massive demolitions in the city and did not include the cultural and architectural values of the city and neglected the mosque. He wanted to create a central square where state facilities were located and a plaza where the presidential object occurred. Brazini wanted to do something from the beginning. That's where the story of "Skanderbeg" square begins, when he places a group of ministries buildings around the square and creates another public space at the end of the boulevard. The boulevard that he creates is related to the fascist theory which creates a strong north-south axis. The squares were created in the break points of the axes and they would later turn into real public spaces. The Scanderbeg 
Square provides an elliptic form where state facilities, ministries, neoclassical buildings were built, but the center of the city still remained the old bazaar area.

The second regulatory plan is that of 1926 , where the city center and the North-southern axis of the boulevard are first contoured and the first public spaces begin to create their characteristics.

The most comprehensive and well-studied regulatory plan was that of 1942. Bosio creates four square systems around the city, 3 main squares.

- The square of power

- The square of ideology

- The church square 2

These are urban spaces, places where people gather. The square of power was called "Skanderbeg" square as it was surrounded by the ministries and main institutions, the square of power was the one at the beginning of the boulevard right in front of today's Polytechnic University building and the church square was supposed to be created at the end of the boulevard which we now call the "train station". "Skenderbeg" square has undergone great transformation over the years. By 1936 the square was designed as a longitudinal square with two circular hooks and with 4 buildings along the northern part, where only one was finally built.

By 1940 the square narrows by creating a flower in the middle. The project includes buildings such as the theater, post office, national bank, offices, municipality, etc which would give a function to that public space.

During the communist period 1945-1990 Tirana went through many changes. The idea of reorganization of the center of Tirana was inspired by the tendencies to deny the past. These changes brought the loss of a part of the city's historic memory, even though the architectural values of collapsed objects were often modest. Tirana's center was conceived as a "monumental space" that would represent Albania's "strength and rebirth". The Old Bazaar of Tirana, the municipality, the Orthodox cathedral, an old ensemble of shops, hotels, bars and a group of characteristic houses were destroyed as "degraded and worthless" objects. By the end of the 80s, the center of the city took an official character, monumental proportions and inhumane reports. With the construction of the National Historical Museum, Scanderbeg Square, destined for political rallies, public manifestations and ideological events took final shape. These major changes that occurred on "Skanderbeg square" also changed the Albanians behavior towards it. This square was one of the most important public spaces people would use at the time to meet and greet and it even created a tradition: "the afternoon walk" that every citizen of Tirana and even visitors would walk there every afternoon to meet their friends and family. Skanderbeg square had turned to the most used public space at the time, as it matched perfectly to the Albanians way of life.

After the 1990 the regime changed to democracy and soon enough "Skanderbeg" square changed its face too. The buildings around it did not change a lot during these years, but the structure of the square itself changed when it became an elongated ellipse with the "Skanderbeg" monument in the middle surrounded by grass that people were not allowed to step on. This change also altered the Albanians behavior towards it, because since that day "Skanderbeg" square did not have a function besides being used as a transition area to move in the city. It was also the centre of the pollution in Tirana. This year "Skanderbeg" square created a new face that most of the citizens love because it matched again their lifestyle. Now "Skanderbeg" square is used a lot for "the afternoon walk" and also is given a specific function during some days with concerts or other events. Besides all the controversy and debate for the "Skanderbeg" square, for which I also have my reserves I believe that it is much better than what it used to be.

${ }^{2}$ Leksione "Urbanistika 2" - Armand Vokshi. 


\section{Our micro spaces proposal for today's Tirana}

I truly believe that Tirana has still a lot of work and change to go through, despite all the change that happened in the past. I believe that is our duty as architects to give a meaning to every public space, however small or big it is, however unimportant it looks, it can make a major change into some people's lifestyle. This is the main reason why we as students wanted to propose some projects to the municipality of Tirana to multiply the number of public spaces and their functions and also create new landmarks through their characteristics. We created a project proposal for many small urban spaces in order to turn them into landmarks. There are dozens of projects, but I further will describe only three of them.

The first micro space is at "Selvia" neighborhood, right in the middle of a crossroad. At the moment it is empty and it is remarkable because of graffiti art to the building next to it, so it already has its character. The point is that this micro space can not be used by the people living in this area, because it is empty. So we proposed a set of sitting areas and trees in order to make it usable by the people and also proposed a set of graffiti drawings on the road that lead to this micro space and make it a small landmark of the area.

The second micro space is the so-called "iso-hip-see" which is a name created by the characteristics of the area. The space has a triangular shape divided into two levels and is now used as a public parking place. We proposed to create a multifunctional space and created a staircase to be used for different events and also many other micro spaces in it that can be used by the children. The whole space works as one with many functions and some entertainment in it, which does not exist at the area at the moment.

The third micro space is next to "Bajram Curri" boulevard between the residential buildings. This area is also used as a public parking and we proposed a structure that will be used by the citizens. We proposed seating and vegetation along with the structure that will turn it into a landmark. The area will be used by children and old people along with a well thought harmony that is going to follow the built structure.

There are some very small changes that have started to grow around the city, that seem unimportant or even unnecessary at first sight,, but when they are done they have the power to change the citizens' life unknowingly. This is the power of a well-thought project that can change the life of thousands if it comes to life correctly. From the day that the municipality security told us "this is a public space, it's not for you" we made it a life goal to show them and every body else in Tirana what "public space" means and why it is so important for our life and our Albanian spirit.

\section{BIBLIOGRAPHY:}

1. Co-Plan, City made by people, 2002.

2. F. Pashako, M. Pessina, A.Vokshi, Interpretimi I hapësirës urbane dhe arkitektonike të aksit strukturues të Tiranës, (The Interpretation of urban and architectural space of the structural axis of Tirana), 2017.

3. Lectures by Prof. Dr. Armand Vokshi, Urban planning 2, 2017.

4. M. Kiel Arkitektura Osmane në Shqipëri 1382-1912 (Ottoman architecture in Albania)", 2012.

5. M. Mitrojorgji, Duke lexuar hapësirën (Reading Space), 2008.

6. M. Mitrojorgji, Forma dhe hapësira (Shape and Space).

7. M. Velo, Tirana konkurse arkitekture, 2003-2005.

8. P. Kolevica, Arkitektura dhe diktatura (Architecture and dictatorial regyme), 2004. 
9. P. Zumthor, Atmospheres, 2007.

10. P. Zumthor, Thinking architecture, 1999.

11. Shqipëria 2030, Plani i integruar ndërsektorial, Tiranë 2015.

12. Wikipedia, History of Albania timeline. 